\title{
Spatial Modeling of Optimum Zones for Wind Farms Using Remote Sensing and Geographic Information System, Application in the Red Sea, Egypt
}

\author{
Hala A. Effat \\ Department of Environmental Studies and Land Use, National Authority for Remote Sensing and Space \\ Sciences (NARSS), Cairo, Egypt \\ Email: heffat@narss.sci.eg, haeffat@yahoo.com
}

Received 1 June 2014; revised 1 July 2014; accepted 28 July 2014

Copyright (C) 2014 by author and Scientific Research Publishing Inc. This work is licensed under the Creative Commons Attribution International License (CC BY). http://creativecommons.org/licenses/by/4.0/

(c) (i) Open Access

\section{Abstract}

Wind power is a safe form of renewable energy and is one of the most promising alternative energy sources. Worldwide, the wind power industry has been rapidly growing recently. It is crucial that the locating of new projects must address both environmental and social concerns. The Red Sea shoreline in Egypt provides excellent wind power potential sites for the Red Sea Governorate. In this study, appropriate zones for wind power farms were mapped using remotely sensed data and a GIS-based model namely Spatial Multi-Criteria Evaluation (SMCE). This model incorporated several criteria, two sets of factors and a set of constraints. First, resource factors included wind speed, elevation zones used to derive the wind power density. Second, economic factors included distances from urban areas, roads and power-lines. Third, land constraints were excluded from the evaluation. The land constraints set included land slope angles, shoreline, urban areas, protectorates airports and ecologically sensitive and historical areas. The Analytical Hierarchy Process was used to assign the criteria relative weights. The weighted criteria and constraints maps were combined in the MCE model. The model identified the zones with potential wind power energy. Such zones were found to exist along the northern parts of the Red Sea shoreline. Some of which are unsuitable due to their location within a sensitive eco-system, high slopes and/or a nearby airport. By excluding such land constrains, the model identified the most appropriate zones satisfying all assigned suitability conditions for wind farms. Ideal zones amount to 706 sq. $\mathrm{km}$ with suitability values ranging from $83 \%$ to $100 \%$ and highly suitable zones amount to 3781 sq. $\mathrm{km}$ having suitability values ranging from $66 \%$ to $83 \%$. 


\section{Keywords}

\section{Wind Power, Remote sensing, GIS, Multicriteria, Red Sea, Egypt}

\section{Introduction}

\subsection{General}

An increase in public awareness regarding the negative impact of traditional power-generating methods, especially coal and oil-fired power stations, has created a demand for using environmentally friendly renewable energy sources. Developing electrical energy from renewable sources is becoming a necessity because it does not release harmful emissions into the environment (Fernandez et al., 2006) [1].

Historically, wind power has been used as a source of power for ships and wind mills. Today, huge wind turbines are used as a renewable energy resource for generating electricity. They are erected in particularly windy places, because wind farms can operate only where steady winds prevail year round.

Various environmental impacts of wind energy are commonly known by scientists. These impacts may be listed as effects on animal habitats (particularly bird collisions), noise generation, visual impact, and electromagnetic interference. A further impact of wind energy on habitat is noise. Example of regulations by authorities as given by Tester at al. (2005) [2]; Ramiraz-Rosado et al. (2008) [3] stated that wind turbines should be located at least $500 \mathrm{~m}$ away from nearest habitat and they studied the visual impact of the wind turbines. Baban and Parry (2001) [4], Nguyen (2007) [5] stated that wind turbines should be located $2000 \mathrm{~m}$ away from large settlements because of aesthetic concerns and safety. According to Yue and Wang (2006) [6] wind turbines must be located at least $500 \mathrm{~m}$ away from wildlife conservation areas and ecological sites such as bird migration sites.

Site selection for large wind turbine requires consideration of a comprehensive set of factors and balancing of multiple objectives in determining the suitability of a particular area for a defined land use (Bennui et al., 2007) [7]. Literature on the siting of wind power facilities generally incorporates the integration of many factors in order to determine a suitable location. Wind resources are the most important criteria. Such resource is classified based on the annual mean wind speed (Patel and Rosier, 2013) [8]. For annual average wind speed between 6 and $10 \mathrm{~m} / \mathrm{s}$ its production varies between 2.4 and 6.5 GWh. Wind farms require a lot of space. Most wind farms fall into a range of $0.1-1 \mathrm{~km}^{2}$ per installed MW (Elliason, 1998; Walker and Jankens, 1997; Afgan and Carvalho, 2002) [9]-[11].

GIS can have significant contribution as a decision support tool in identifying environmentally feasible locations for wind turbines which require management and analysis of wide range of spatial data types. GIS analysis might aid to determine appropriate zones according to specific criteria for future development. A MCE is the evaluation of a set of alternatives, based on multiple factors and constraints, where the factors are quantifiable indicators of the extent to which decision objectives are realized (Malczewski, 1999) [12]. The most important factor in MCE is how to establish "weights" for a set of criteria according to importance. Location decisions such as the ranking of alternative communities are representative multi-criteria decisions that require prioritizing multiple criteria. A MCE enables the outcomes to be visualized in maps (Wood and Dragicevic, 2007) [13]. One of the most useful GIS decision making tools is the Analytical Hierarchy Process (AHP). This process is a comprehensive, logical and structural framework, which allows analyzer to improve the understanding of complex decisions by decomposing the problem in a hierarchical structure. Such structure shows the relationship between the goal, objectives, criteria, and alternatives (Bennui et al., 2007) [7]. This will also allow for unique ecological, social, economic and/or combined scenarios to be modeled (Mann et al., 2012; Bartnicki and Williamson, 2012) [14] [15]. This process enables the analyst to perform multiple scenarios by altering factor weights depending on the user's preference.

Different modeling approaches have been conducted to arrive to the most appropriate sites for wind farms. Economic factors for the siting of wind power facilities include wind speed and/or wind power density and distance to hydro lines, roads and slopes. Socially influenced factors included distance from urban areas and historic sites. Environmental variables generally included distance from wetlands, forests and water bodies (Baban and Perry, 2001; Mann et al., 2012; Rodman and Meentemeyer, 2006; Bartnicki and Williamson, 2012) [4] [14]-[17]. 


\subsection{Wind Energy in Egypt}

In fact, limited primary energy resources are consumed in Egypt. The most important of these resources are oil, natural gas, coal and hydropower. In addition, new and renewable energy resources such as solar and wind have a good potential. Due to its geographic location and varied topography, Egypt has some good locations with an average wind speed reaching $10 \mathrm{~m} / \mathrm{sec}$ capable of producing competitive wind energy from wind turbines.

Since the early 1980's renewable energy has been considered as an integral part of the Egyptian policy. In a significant move, the Egyptian Government has launched a national program to apply new and renewable energy technologies. A new and Renewable Energy Authority (NREA) was established in 1986. The NREA's objectives are to introduce renewable energy technologies to Egypt on a commercial scale. The Egyptian Renewable Energy Development Organization (EREDO) was established in 1992 by mutual financing from Egypt and European Communities, covering renewable energy technologies, testing and endorsing certificates of components. The government program includes wind to supply energy to remote areas, which are located far from the grids, or directly to the grid in case of large wind power generation.

Recent achievements have been realized in the areas of institutional building, field testing, technology adoption and development of local wind industries. Currently, a wind farm of $6 \mathrm{MW}$ is operative at Zafarana on the Gulf of Suez coast, where the first large commercial wind farm of $60 \mathrm{MW}$ is being developed. Rapid penetration of different applications in many sectors is expected in the next few years, especially for the extension of the windelectricity generation.

\subsection{Description of the Red Sea Governorate}

The Red Sea Governorate extends in a northwesterly direction between latitude $22^{\circ} \mathrm{N} 30^{\circ} \mathrm{N}$. It is bordered from the east by the Red Sea and the Gulf of Suez coastal line and from the west by the eastern desert (Figure 1). The Red Sea coast line extends for $1080 \mathrm{~km}$ from the Gulf of Suez at latitude $29^{\circ} \mathrm{N}$ to the borders of Sudan at latitude $22^{\circ} \mathrm{N}$. Area is equivalent to 120 thousand sq. km. and comprising six cities; Ras Gharib, Hurghada, Safaga, El Quseir, Marsa Alalm, and Shalateen. Between the Eastern Desert mountains and the Red Sea shoreline, there is a coastal plain of almost level land that extends along the edges of the Gulf of Suez and the Red Sea. The width of such ranges from 8 to $35 \mathrm{~km}$.

The Red Sea Coast is characterized by a dominantly hot, dry and windy climate. In Hurghada city for example the annual average temperature is $24.5^{\circ} \mathrm{C}$, the relative humidity is $79.6 \%$, evaporation is $9.8 \mathrm{~mm}$ per day. The annual amount of rainfall is $4 \mathrm{~mm}$. Thus the area is arid with sparse vegetation. The wind speed reaches $7.6 \mathrm{~m} / \mathrm{sec}$ and of dominating NW direction. In some zones, the wind speed may reach $10 \mathrm{~m} / \mathrm{sec}$ which is a high potential for wind energy.

The population of the Red Sea Governorate live in a number of cities on the coastline and few scattered villages in between. Tourist resorts are spreading down all coastlines. Egyptian Red Sea coast in general has very limited freshwater resources due to its geographical location in the arid sub-tropical region. The Egyptian Red Sea is also a major transportation route due to the Suez Canal and a key location for petroleum and natural gas production. The Red Sea Governorate is the richest province of the republic in mining and mineral potentials. It has the vast majority of metallic and non-metallic ores and ornamental stones and is quite rich in investment opportunities.

The economic base is partially tourism, which is nature based, occupying a large portion along the Red Sea shores. The Red Sea Governorate is rich in biodiversity providing potentials for ecotourism and nature preservation. Based on Shobrak et al. (2003) [17] and Baha El Din et al. (2003) [18], Egypt comprises a wide range of habitats critical for birds. These include: wetlands, high altitude mountains, desert wadis, coastal plains and marine islands (Egyptian Environmental Affairs Agency, 2014) [19]. The Red Sea islands of Tiran, Ashrafi, North Qeisum, Tawila and Zabargad are amongst the most important islands in the Egyptian Red Sea for breeding seabirds. About 150 of birds species are considered as resident with breeding populations (Baha El Din, 1999) [20]. Within birds populations, 16 species of global conservation concern have been recorded in Egypt (Collar et al., 1994) [21]. The region is internationally famous for diving activities. Fishing is another important economic activity in the region (Baha El Din et al., 2003) [18].

Development in Red Sea Governorate faces two main challenges; water and energy. The governorate has potentials for renewable energy such as solar and wind energy. Renewable energy can therefore be the backbone for development. Provision of necessary power can provide water by desalination of water from the Red Sea. Less than $1 \%$ of Egypt's current energy mix comes from wind, despite an abundance of wind resources, particularly in 


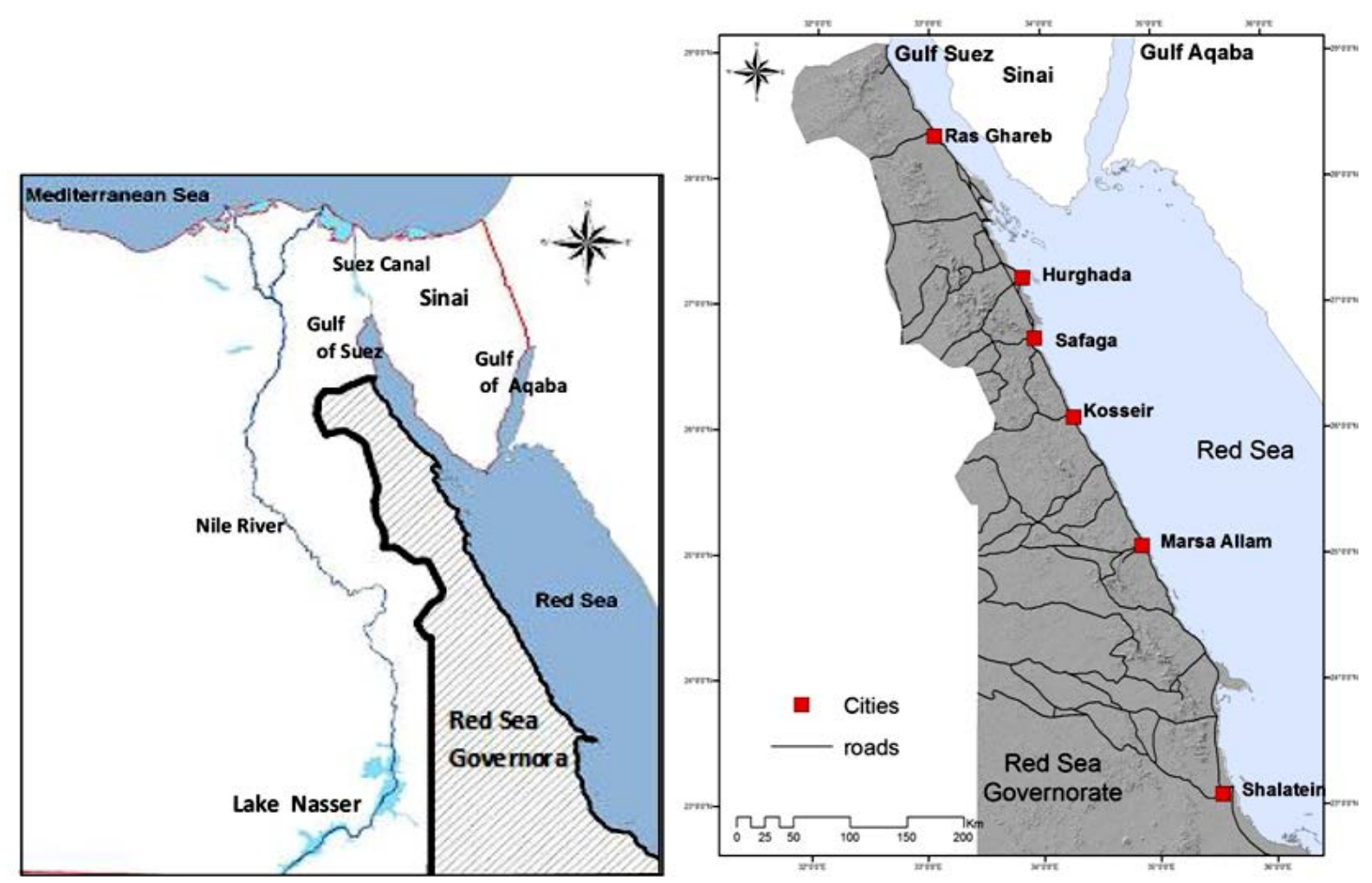

Figure 1. Location of the study area.

the Gulf of Suez area. As of 2008/2009, Egypt's Renewable Energy Authority (NREA), affiliated with the Ministry of Electricity manages Egypt's clean energy portfolio. It has installed $425 \mathrm{MW}$ of wind power, including a wind farm at Zafarana, in Suez Governorate. Such wind farm has been operational since 2004 and has a capacity of $360 \mathrm{MW}$, where wind averages 9 meters/second (Shata and Hanitsch, 2006) [22]. A record summary of wind observations at some meteorological stations in Red Sea and Gulf of Suez is shown in Table 1.

\section{Materials Used in the Study}

Several data and information were collected, from the different sources to be used in order to achieve the overall objectives of this study, these include:

\subsection{Remote Sensing Data: Optical and Radar Data Were Used for This Study as Follows}

1) Landsat ETM+ images, to delineate shoreline and to investigate land use/land cover patterns.

2) Shuttle Radar Topography Mission (SRTM) elevation and derived land slope.

\subsection{Maps}

Various types of maps covering the study area have been compiled, digitized. All data were projected to WGS-84 of the Universal Transverse Mercator System (UTM) of geographic coordinates. The digitized layers were imported to a geographic database using ESRI ArcGIS 9.3 software [24].

These include:

1) Topographic maps at scale 1:50,000 published by the Egyptian General Survey Authority (1989) [25].

2) Climatic Atlas of Egypt, published by the Egyptian Meteorolgical Authority (1996) [26].

3) Wind Atlas of Egypt, published by Mortensen et al. (2005) [23].

4) Map of natural protectorates and birds sites, published by the Egyptian Environmental Affairs Agency (EEAA) [19].

A description of the main GIS layers used and sources is presented in Table 2. 


\section{Methodology}

\subsection{Theory and Approach}

Spatial Multi-Criteria Evaluation (MCE) was conducted using analytical approach to determine suitable locations for the project. Analytical Hierarchy Process (AHP) is a multi-criteria decision method that uses hierarchical structures to represent a problem and then develop priorities for alternatives based on the judgment of the user (Saaty, 1980) [27]. The AHP procedure involves five essential steps (Lee et al., 2008) [28]: 1) Develop the AHP hierarchy; 2) Pairwise comparison; 3) Estimate the relative weights; 4) Check the consistency; 5) Obtain the overall rating.

1) Develop the AHP hierarchy: In this step the complex problem is decomposed into a hierarchical structure with decision elements i.e.: objective, attributes or criterion map layers and alternatives (Vahidniaa et al., 2008) [29].

2) Pairwise Comparison: AHP method is based on pair-wise comparison within a reciprocal matrix, in which the number of rows and columns is defined by the number of criteria. Accordingly, it is necessary to establish a comparison matrix between pairs of criteria, contrasting the importance of each pair with all the others. The comparison ratings are provided on a nine-point continuous scale, which was proposed by Eastman (1995) [30]. If we call that weight $a_{i j}$, and use that scale of comparison and if the relative weighting is $a_{23}=3 / 1$, then the relative importance of attribute 3 with regard to 2 is its reciprocal $a_{32}=1 / 3$. This process generates an auxiliary matrix in which the value in each cell is the result of the division of each value judgment $\left(a_{i j}\right)$ by the sum of the corresponding column. Finally, the average of the normalized values of rows is obtained, which corresponds to the priority vector $\left(W_{j}\right)$. This is normalized by dividing each vector value by n (the number of vectors), thus obtaining

Table 1. A record summary of wind observations at some meteorological stations in the Red Sea and Gulf of Suez: Datacollecting period, height above ground level of anemometer, data recovery rate (R), Weibull $A$ and $K$ parameters, mean wind speed (U), mean power density (E), and direction (DU), magnitude (U) of the mean wind vector. (Source: Mortensen et al., 2005) [23].

\begin{tabular}{|c|c|c|c|c|c|c|c|c|c|}
\hline Region/Station & period & Height [m] & $\mathrm{R}[\%]$ & $\mathrm{A}\left[\mathrm{m} \cdot \mathrm{s}^{-1}\right]$ & $\mathrm{k}$ & $\mathrm{U}\left[\mathrm{m} \cdot \mathrm{s}^{-1}\right]$ & $\mathrm{E}\left[\mathrm{W} \cdot \mathrm{m}^{-2}\right]$ & $\mathrm{D}_{\mathrm{U}}$ [deg] & $|\mathrm{U}|\left[\mathrm{m} \cdot \mathrm{s}^{-1}\right]$ \\
\hline \multicolumn{10}{|l|}{ Gulf Suez } \\
\hline Ras Ghareb & $5 y$ & 24.5 & 85.5 & 11.0 & 3.40 & 9.9 & 775 & 322 & 8.7 \\
\hline \multicolumn{10}{|l|}{ Red Sea } \\
\hline Hurghada WETC & $11 y$ & 24.5 & 79.6 & 7.6 & 2.32 & 6.7 & 308 & 322 & 4.9 \\
\hline Hurghada (62463) & $10 y$ & 10.0 & $\mathrm{n} / \mathrm{a}$ & 7.6 & 2.66 & 6.7 & 285 & 325 & 5.4 \\
\hline Kosseir (62465) & $4 y$ & 10.0 & 97.1 & 5.1 & 2.03 & 4.6 & 178 & 334 & 3.5 \\
\hline Kosseir & $4 y$ & 24.5 & 88.7 & 6.5 & 2.32 & 5.8 & 197 & 321 & 4.3 \\
\hline
\end{tabular}

Table 2. Description of GIS data layers used in the current study.

\begin{tabular}{|c|c|c|}
\hline GIS data layer & Description & Data Source \\
\hline Vector (polygon) & Wind speed & Ministry of Electricity and Energy \\
\hline Raster & Elevation & Shuttle Radar Topography Mission (SRTM) \\
\hline Raster & Slope & Shuttle Radar Topography Mission (SRTM) \\
\hline Vector (line) & Power lines & $\begin{array}{c}\text { Topographic map, scale 1:50,000, Egyptian General Survey } \\
\text { Authority } 1989\end{array}$ \\
\hline Vector (line) & Highways & Ministry of Transportation \\
\hline Vector (point) & Airport areas & General Organization for Physical Planning \\
\hline Vector (polygon) & Birds sites & General Organization for Physical Planning \\
\hline Vector (polygon) & National Protectorates & Egyptian Environmental Affairs Agency (EEAA) \\
\hline Vector (point) & Cities and urban settlements & General Organization for Physical Planning \\
\hline Vector (point) & Archaeology sites & General Organization for Physical Planning \\
\hline Raster & Land use/land cover & $\begin{array}{l}\text { Classification of Landsat ETM + imagery and } \\
\text { FAO Africover data for Egypt }\end{array}$ \\
\hline Vector & Shoreline & Digitized from Landsat ETM + imagery \\
\hline
\end{tabular}


the normalized overall priority vector, representing all factor weights $\left(W_{j}\right)$ (Table 3(a)).

3) Estimate the relative weights: To determine the weighted sum vector we multiplying matrix of comparisons on the right by the vector of priorities to get a new column vector. Then divide first component of new column vector by the first component of priorities vector, the second component of new column vector by the second component of priorities vector, and so on. Finally, sum these values over the rows.

4) Estimation of the consistency vector: To calculate the consistency vector we divide the weighted sum vector by the criterion weights. Once the consistency vector is calculated it is required to compute values for two more terms, lambda $(\lambda)$ and the consistency index (CI). The value for lambda is simply the average value of the consistency vector. The calculation of CI is based on the observation that $\lambda$ is always greater than or equal to the number of criteria under consideration (n) for positive, reciprocal matrices and $\lambda=\mathrm{n}$, if the pair wise comparison matrix is a consistent matrix. Accordingly, $\lambda-\mathrm{n}$ can be considered as a measure of the degree of inconsistency and

$$
\mathrm{CI}=(\lambda-\mathrm{n}) /(\mathrm{n}-1)
$$

The term CI, referred to as consistency index, provides a measure of departure from consistency. To determine the goodness of CI. The consistency ratio (CR) can be defined as follows:

$$
\mathrm{CR}=\mathrm{CI} / \mathrm{RI}
$$

where Random Index (RI) is the CI of a randomly generated pairwise comparison matrix of order 1 to 10 obtained by approximating random indices using a sample size of 500 (Saaty, 1980) [27]. Table 3(b) shows the value of RI sorted by the order of matrix.

The consistency ratio (CR) is designed in such a way that if $\mathrm{CR}<0.10$, the ratio indicates a reasonable level of consistency in the pairwise comparisons; if, however, $\mathrm{CR}>0.10$, then the values of the ratio are indicative of inconsistent judgments.

5) Overall rating: A weighted linear combination (WLC), a simple additive weight method was used to combine the criteria and constraints to yield the suitability map as follows:

$$
S=\sum\left(W_{j} \times X_{i j}\right) \Pi(\text { constraint map })
$$

$S$ = composite suitability score,

$W_{j}=$ weights assigned to each factor $j$,

$X_{i j}=$ attribute score $i$ of factor $j$.

Table 3. (a) AHP weighting scale (Saaty, 1980); (b) Random index (RI) (Saaty, 1980) [27].

(a)

\begin{tabular}{cccc}
\hline Intensity & Definition $\left(i\right.$ in regards to $\left.a_{j}\right)$ & Values & Numbers \\
\cline { 2 - 3 } Relative importance & Equal importance & $a_{i j}$ & $a_{j i}$ \\
\hline 1 & Intermediate & 1 & 1 \\
2 & Moderate importance & 2 & $1 / 2$ \\
3 & Intermediate & 3 & $1 / 3$ \\
4 & Strong importance & 4 & $1 / 4$ \\
6 & Intermediate & 5 & $1 / 5$ \\
7 & Very strong importance & 6 & $1 / 6$ \\
9 & Intermediate & 7 & $1 / 7$ \\
\hline
\end{tabular}

(b)

\begin{tabular}{cccccccccccc}
\hline Order Matrix & 1 & 2 & 3 & 4 & 5 & 6 & 7 & 8 & 9 \\
RI & 0.00 & 0.00 & 0.58 & 0.9 & 1.12 & 1.24 & 1.32 & 1.41 & 1.45 \\
\hline
\end{tabular}




\subsection{Application on the Red Sea Governorate}

\subsubsection{Evaluation Criteria for Zoning Potential Wind Farms}

Evaluation criteria are grouped into factors and constraints. Factors are criteria that promote the development of a certain activity. Constraints are concerned with the zones that could be negatively affected by a specific activity. It is thus such zones that should be avoided and/or protected from change. In GIS analysis, the constraints issue can be solved by keeping a set-back zones or buffer zones. A buffer zone is decided by setting a threshold value. The distance from a facility can be either a factor or a constraint or both. For example getting closer to a main road can be an economic factor that minimize transportation costs. Yet, getting too close to such road could be non-aesthetical, cause accidents, noise, compete with other land-use. It is therefore, necessary to reach a threshold that limits the factor from the constraint for a wind farm siting decision

\subsubsection{Criteria and Thresholds}

The preferences of each group for geographical locations use a set of specified criteria. For example, the environmentalists group can select maps of the impact of wind farms, or maps of the distances of wind farms ecologically sensitive areas due to bird collisions. Wind energy resource is the most important criteria for siting a wind energy farm. While performing site selection, both the wind energy potential and environmental acceptability/fitness need to be considered. A location which does not have sufficient wind energy potential is not an appropriate location for wind turbines no matter how high it satisfies all acceptability objectives and concerns. A conceptual flow chart for the criteria and methodology is shown in (Figure 2).

\subsubsection{Wind Power Density}

According to (Mortensen et al., 2005) [23] the wind resources of Egypt have recently been assessed by the New and Renewable Energy Authority, the Egyptian Meteorological Authority and Risø National Laboratory; (NREA) the results are reported in detail in a Wind Atlas for Egypt. The primary purpose of the Atlas is to provide reliable and accurate wind atlas data sets for evaluating the potential wind power output from large electricity-producing wind farms. Numerical wind atlas methodologies have been used to solve the issue of insufficient wind measurements based on meteorological stations. Based on Mortensen et al. (2005) [23], the KAMM/WAsP method was developed and used by Riso laboratory to produce estimates of wind resource on a national scale. A predicted map for wind climate of Egypt was determined by meso-scale modeling. The map shows the mean wind speed in $\left[\mathrm{m} \cdot \mathrm{s}^{-1}\right]$ at height of $50 \mathrm{~m}$ over the actual land surface. The horizontal grid point resolution is $7.5 \mathrm{~km}$.

The wind power in a given site depends on having sufficient wind speed available at the height at which the turbine is to be installed (Vanek and Albright, 2008) [31]. Wind power density is a most important factor because it provides information on the most feasible and profitable areas in the region for siting a wind power project (Baban and Perry, 2001) [4]. Bartniki and Williamson, 2012 [15] explain that wind power density is a function of the area's average wind velocities and the air densities, which involves land elevations. The wind power density is derived by Equation (4) and Equation (5) (Hughes, 2000) [32].

$$
\begin{gathered}
\rho=1.225-\left[\left(1.194 \times 10^{-4}\right) \times \text { elevation }(\mathrm{m})\right] \\
w p d=1 / 2 \rho V^{3}
\end{gathered}
$$

where: $V=$ average wind speed $(\mathrm{m} / \mathrm{s}) ; \rho=$ air density $\left(\mathrm{kg} / \mathrm{m}^{3}\right) ; w p d=$ wind power density $\left(\mathrm{watt} / \mathrm{m}^{2}\right)$.

Shuttle Radar Topography Mission SRTM digital elevation model (figure) was used to model the air density using (Equation (4)). The wind speed energy map (V) developed by Mortensen et al., 2005 [23] was downloaded geometrically corrected, digitized, projected, converted to raster format and a resample function was applied. The data was finally used to calculate the wind power density using Equation (5).

\subsubsection{Power-Lines Proximity and Setback Buffer}

A suitable location will need to be in close proximity to existing roads and hydro lines to minimize production costs (Nextra Energy Canada, 2011 [33]; Bartnicki and Williamson, 2012 [15]). The distance to transmission lines is a necessity in order to transport the energy created by the wind turbines and reduce costs. Land that is connected to an electrical grid therefore provides a more suitable site. For setback distance, according to Moiloa 2009 [34] and the DEADP, 2006 [35] suggests a minimum distance of 250 meters should be kept apart from high voltage 


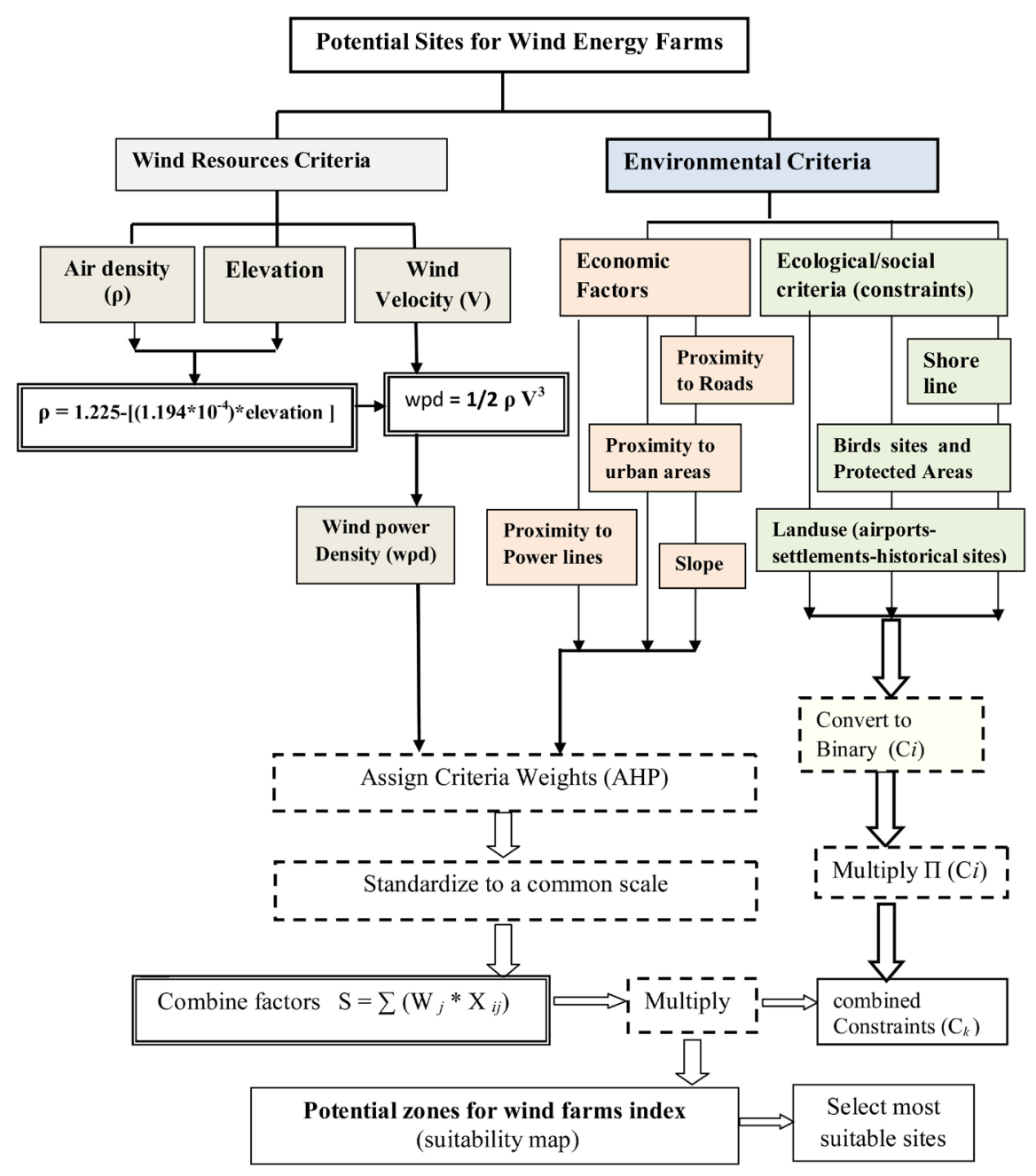

Figure 2. A conceptual chart for the applied methodology.

lines. Same distance was considered for the current study.

\subsubsection{Roads Proximity and Setback}

Wind farms should be set apart from roads and railroads. According to Moiloa, 2009 [34] and the DEAP 2006 [35] suggested a distance of $2.5 \mathrm{~km}$ from main roads and railroads and a distance of 500 meter from secondary roads. Construction costs start to increase the further away a project is from existing roads due to the need for new road construction (Bartniki and Williamson, 2012) [15]. A distance function was used to classify the region, where the areas closer to the roads setback buffers were given high suitability while areas further to the buffer were given low suitability. For the present study, a setback of $500 \mathrm{~m}$ was used.

\subsubsection{Urban Areas and Cultural Sites Proximity and Setback}

CNdV Africa 2006 [36] report defines heritage sites as sites of historical and cultural value either with national or provincial designations. These sites are considered cultural amenities that should be protected. Bartnicki and Willamson, 2012 [15] used a $550 \mathrm{~m}$ setback for urban, recreational and historic areas are granted. For the current study, a setback of $1000 \mathrm{~m}$ was used for historic sites while $2000 \mathrm{~m}$ was used for cities to account for growth expansion.

\subsubsection{Slopes}

Luo et al., 2007 [37], Bartnicki and Williamson 2012 [15] explain that at the summit of steep slopes wind may not 
hit the turbine rotor at a perpendicular angle. This will result in an increased level of fatigue for the turbine. Thus a slope of greater than 5 degrees will yield more turbulent wind patterns causing disruptions in turbine stability. Building on higher slopes also increases project costs. Ideally, the terrain should be rounded or flat because they will be exposed to higher, more constant wind speeds (Baban and Parry, 2001) [4]. The slope was reclassified to three categories with most suitable for flat to 5 degrees and unsuitable for slopes greater than 10 degrees and marginally suitable for values in between.

\subsection{Ecological and Social Factors (Exclusion Zones/Constraints)}

Ecological and social evaluation criteria can be factors or constraints. A constraint or an exclusion zone is restrictedly unsuitable zone for wind turbine installation. It is excluded for protecting effects on environment, communities, visualization, eco-conservation, and engineering frontier (Bennui et al., 2007) [7]. For constraint criteria, a threshold was assigned. Such threshold classifies a criteria raster into suitable and unsuitable pixels using a binary classification (Effat and Hegazy, 2013; Effat, 2014) [38] [39]. Suitable pixels are assigned a value of "one" while unsuitable pixels are assigned a "zero" value. In the last stage of data analysis, inappropriate zones will be combined in a single constraints binary map and excluded. Constraints for the present study are explained as follows:

\subsubsection{Shoreline Setback}

Wind farms should be set apart from inhabited areas. According to Moiloa, 2009 [34] and the DEAP, 2006 [35] suggested a setback distance of $4 \mathrm{~km}$ from the coast. A similar buffer zone was used around the shoreline considering possible birds flight paths and future tourism marine activities.

\subsubsection{Protected Areas (Cultural, Ecological and Birds Areas)}

Regionally important geological/geomorphologic sites, and other natural reserves are protected by national legislations. Such lands were considered constraints as the development of a wind farm may have a significant impact on the environmental values of such areas. According to Moiloa, 2009 [34], the DEAP 2006 [35] a distance of 500 meter from nature reserves and a distance of $1 \mathrm{~km}$ from national protectorates, nesting areas and flying routes of protected species is appropriate. CNdV Africa 2006 [36] used a distance of $2 \mathrm{~km}$ from national protectorates for the development of Western Cape, South Africa. For the present study, a distance of $1 \mathrm{~km}$ around the natural protectorates and ecological sites was considered appropriate.

\subsubsection{Land-Use-Land-Cover}

Certain land-use have to be set apart from wind farms. Airports is one the most important as navigation can be affected by such operations. CNdV Africa (2006) [36] applied a distance of $25 \mathrm{~km}$ from airport with primary radar for the development of Western Cape. Same distance was adopted as buffers for the airports.

\subsubsection{Developing a Pairwise Comparison Matrix}

The Pairwise Comparison Matrix used for the present study was developed based on the review of relevant literature. However, there could be a different judgment for the relative magnitude of the criteria when these are compared in pairs. The decision making process in the multiple criteria problems is a subjective process depending on the decision maker vision.

\subsection{Standardization of the Criteria}

For each factor, the attributes were standardized by transforming the original values to a suitability value using Saaty's, (1980) [27] suitability scale from 1 - 9. The higher value is more favorable and vice versa. Areas deemed as constraints will have a suitability score of zero. Areas with a higher suitability will have a higher score (Bartnicki and Williamson, 2012) [15].

\subsection{Combining the Criteria}

Evaluation criteria were combined in a grid that contains all standardized grids calculated from each of the individual grids. All the input evaluation criteria were in standardized raster grid format and with a $100 \mathrm{~m}$ cell size. Equation (3) generates a suitability grid that ranks the suitable areas by percentage. 


\section{Results and Discussion}

The study was conducted using satellite data from Landsat ETM+ and SRTM and geographic information systems (GIS) for mapping the suitability of the Red Sea Governorate for siting wind farms. Results revealed that coastal areas along the Gulf of Suez and the northern zones of the investigated region have high wind energy potentials. Such zones are appropriate for setting up electricity generating wind turbines. The total investigated area is equivalent to 120 thousand sq. $\mathrm{km}$. Most suitable zones amounts to $706.5 \mathrm{sq}$. km with suitability percent ranging between $83 \%$ and $100 \%$ and highly suitable zones amounting to 3781 sq. km having suitability percent that range from $66 \%$ to $83 \%$. The results reveal that the northern part of the investigated area is quite rich in wind power potentiality. Results can be explained as follows:

\subsection{Wind Power Map (Wind Resources Criteria)}

The study revealed that coastal areas along the Gulf of Suez and the northern zones of the Red Sea coast with an area equivalent to 120 thousand sq. km have high wind energy potentials. Such zones are appropriate for setting up electricity generating wind turbines. The calculations of wind power density from the wind speed maps reveal a maximum value is around $660 \mathrm{watt} / \mathrm{m}^{2}$ and a mean value of $97 \mathrm{watt} / \mathrm{m}^{2}$. The elevation, air density, average wind velocity and the resultant wind power density maps are presented in Figures 3(a)-(d) respectively.

\subsection{Economic Criteria Maps and Standardization}

The standardized economic criteria maps for distance to roads, distance to power lines, distance to settlements are depicted in Figures 4(a)-(c). The slope suitability attrubyte map is shown in Figure 5. Assigned weights resulting from applying Analytical Hierarchy Process (AHP) are presented in Table 4. The standardized attribute values based on suitability for siting wind energy zones are presented in Table 5.

\subsection{Ecological and Cultural Criteria Maps (Constraints)}

The ecological and cultural values criteria maps are binary maps. Such maps are presented in Figure 6. In each of the constraints maps, the excluded zones are presented in black color while the rest of the study area is presented in white color. Figures 6(a)-(f) depict the excluded zones for the national protectorates, shoreline, airports, cities, main roads and birds sites respectively. The set back buffer zones are described in Table 6.

\subsection{Suitability Map}

The suitability index values resulting from the overlay (suitability function) was classified into five suitability classes. Each class representing a suitability range (Table 7).

Most suitable zones of class 5 have wind velocity that range between 8.0 to $11.0 \mathrm{~m} / \mathrm{sec}$. and wind power density ranging between 543 to 659 watt $/ \mathrm{m}^{2}$ is a huge energy potentiality and flat lands. Such class exists along the north-east shores of Gulf Suez and Red Sea and extend inlands towards the west. Two airports exist in such zone namely Ras Shukhayr new airport and Ras Jismah new airport. Such airports necessitates setback buffers each of which is assigned an area of 20 - $25 \mathrm{~km}$ for proper navigation needs. In addition, ecological areas for bird flight sites and high slope lands were excluded. Suitable net areas for class 5 is equivalent to 706.7 sq. km with suitability values from $84 \%-100 \%$ (Figure 7).

Highly suitable zones in class 4 area have wind power density ranging between $310-425 \mathrm{watt} / \mathrm{m}^{2}$ and a land area equivalent to 3781.2 sq. $\mathrm{km}$ after subtraction of setback buffers and constraints. This class exists almost parallel to the Gulf Suez and the northern parts of the Red Sea , mostly flat lands to very gentle slopes (less than 9 degrees) and are in close proximity to class 5 (Figure 7). Suitability values for this class range from 65\% to 83\%.

Moderately suitable zones in class 3 have wind velocity range of $4.5-6.4 \mathrm{~m} / \mathrm{sec}$ which is acceptable to good, but the slopes are quite steep. The slope constraint cause more turbulent wind patterns and may cause disruptions in turbine stability and also reduces the suitability values. Net area of such class is around 35,300 sq. km with suitability values ranging from $50 \%$ to $65 \%$ (Figure 7 ).

Less suitable zones in class 2 have wind velocity range of $4.5-5.0 \mathrm{~m} / \mathrm{sec}$. which is marginally acceptable. Steep slopes exceed the accepted threshold (greater than 9 degrees) in such areas which in turn lead to low sui- 


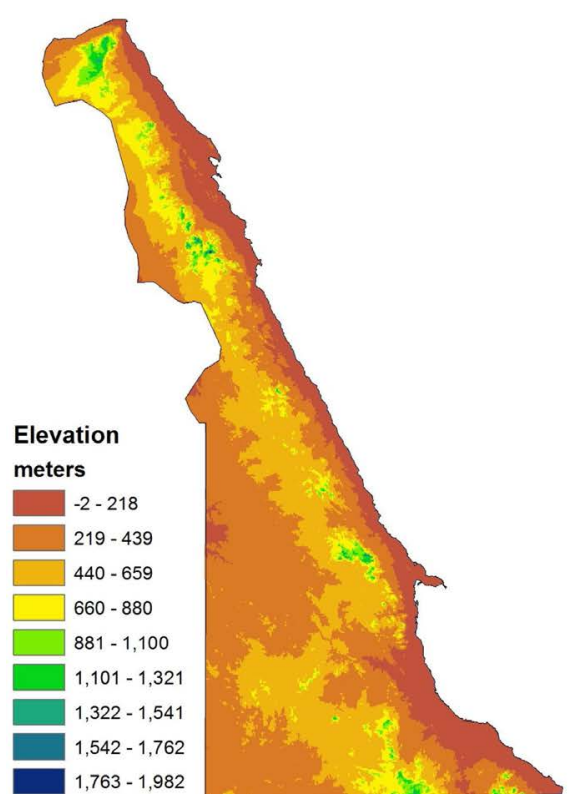

(a)

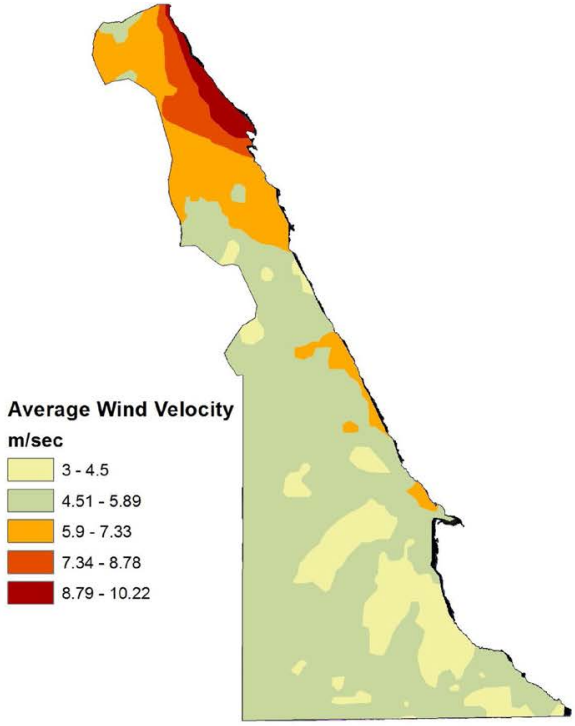

(c)

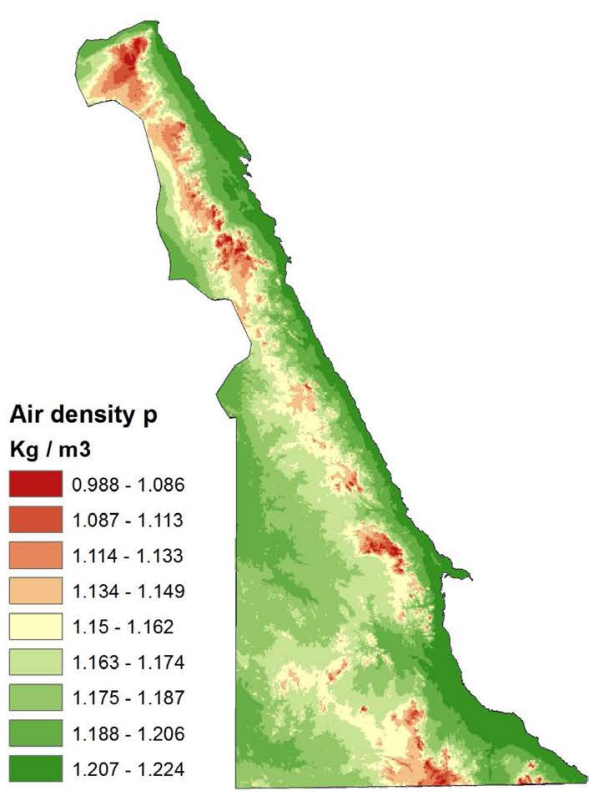

(b)

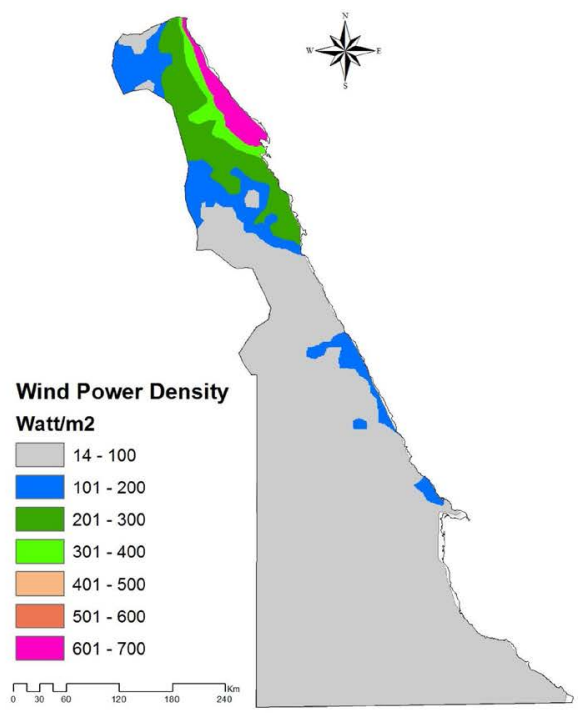

(d)

Figure 3. Wind power density evaluation criteria (grids in true value categories) (a) elevation; (b) air density; (c) average wind velocity; and (d) wind power.

tability values. Total area of such class is equivalent to $45,690.7 \mathrm{sq}$. $\mathrm{km}$ with suitability values ranging from $31 \%$ - 49\% (Figure 7).

Unsuitable zones in class 1 are excluded zones (zones treated as constraints). Total area of such class is equivalent to $35,298.8 \mathrm{sq}$. km and a suitability range ( $0-30 \%)$. Regardless of the wind velocity, such zones were excluded for ecological, social and economic reasons (Figure 7).

\section{Conclusion and Recommendation}

The current study employed remotely sensed data in a GIS-based multi-criteria evaluation model to identify and map appropriate zones for wind energy farms. The method was quite flexible in creation of the evaluation criteria, assigning importance weights, standardization and map overlay. It provides visual intermediate and final results in 


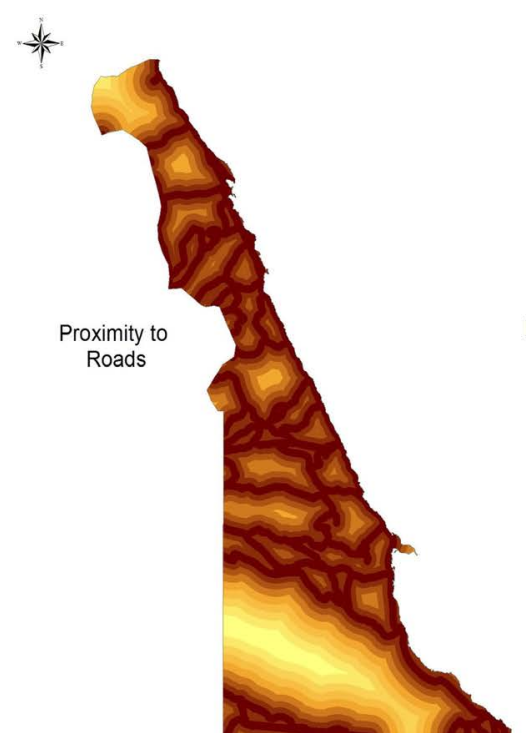

(a)

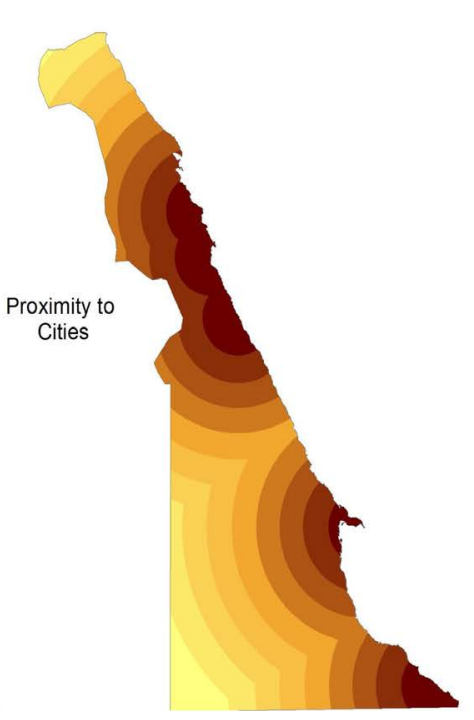

(b)

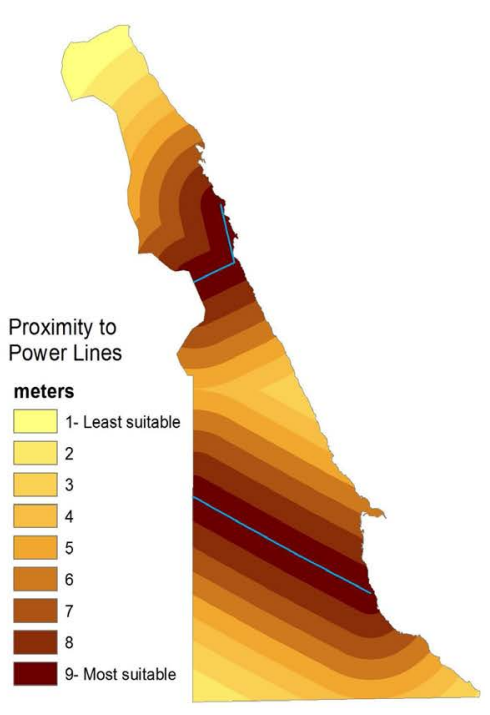

(c)

Figure 4. Standardized suitability grids for economic evaluation criteria: (a) proximity to roads; (b) proximity to cities; (c) proximity to power lines.

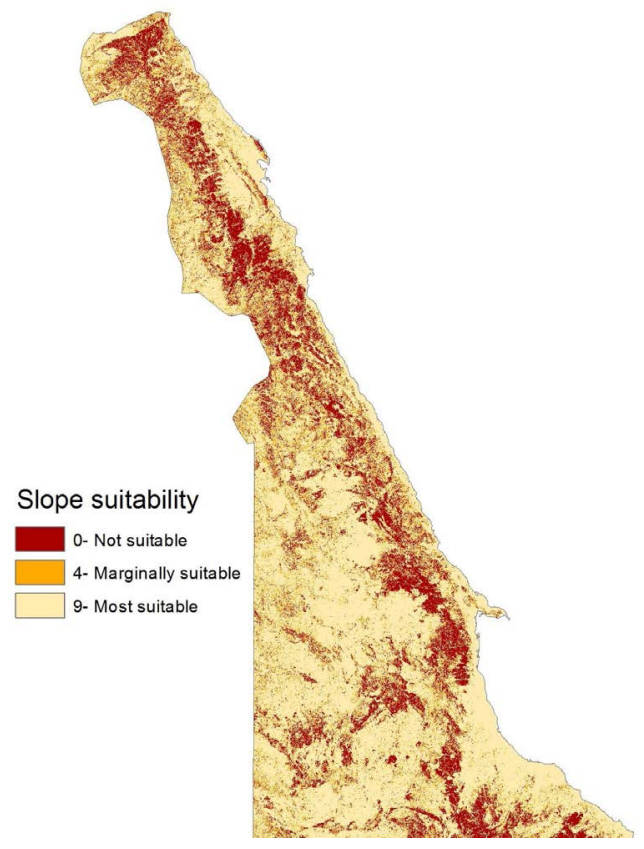

Figure 5. Suitability grid for slope.

Table 4. Pairwise comparison matrix for criteria weight assignment.

\begin{tabular}{cccccc}
\hline Criteria & $\begin{array}{c}\text { Wind power } \\
\text { density }\end{array}$ & $\begin{array}{c}\text { Slope } \\
\text { (degrees) }\end{array}$ & $\begin{array}{c}\text { Proximity to } \\
\text { power lines }\end{array}$ & $\begin{array}{c}\text { Proximity to roads } \\
\text { urban centers }\end{array}$ & $\begin{array}{c}\text { Calculated } \\
\text { weight }\end{array}$ \\
\hline Wind power density $\left(\mathrm{W} / \mathrm{m}^{2}\right)$ & 1 & 4 & 7 & 9 & 9 \\
Slopes & $1 / 4$ & 1 & $7 / 4$ & $9 / 4$ & $9 / 4$ \\
Proximity to Power Lines & $1 / 7$ & $4 / 7$ & 1 & 1 & $9 / 7$ \\
Proximity to Roads & $1 / 9$ & $4 / 9$ & $7 / 9$ & 1 & 0.088 \\
Proximity to Urban centers & $1 / 9$ & $4 / 9$ & $7 / 9$ & 0.068 & 1 \\
\hline
\end{tabular}




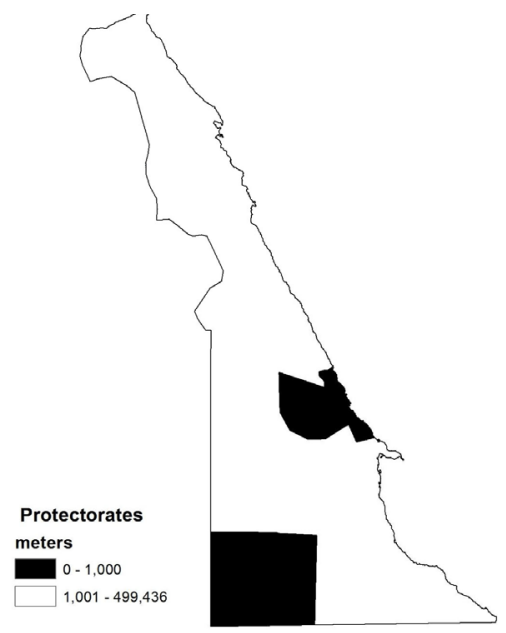

(a)

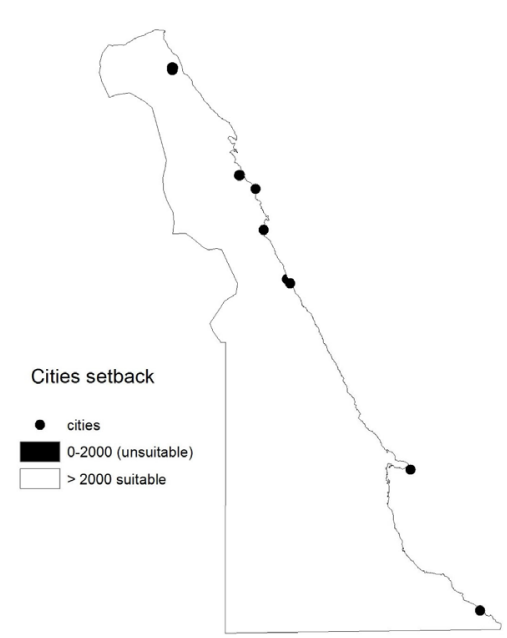

(d)

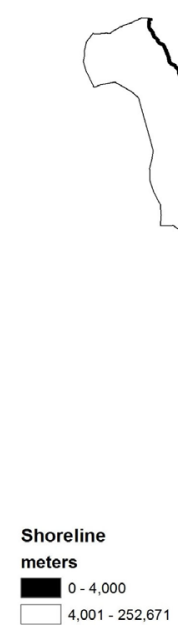

(b)

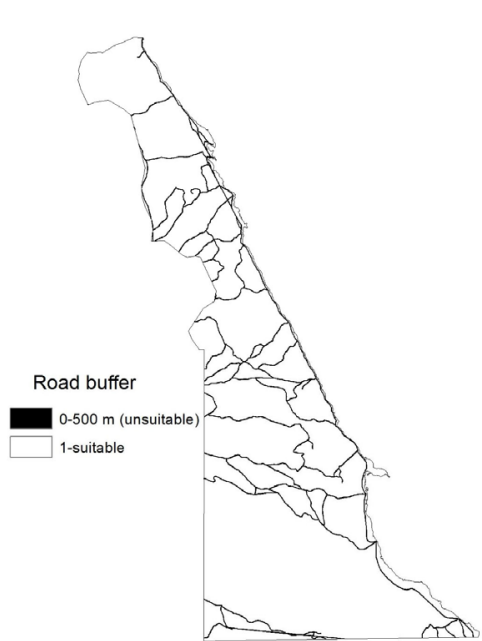

(e)

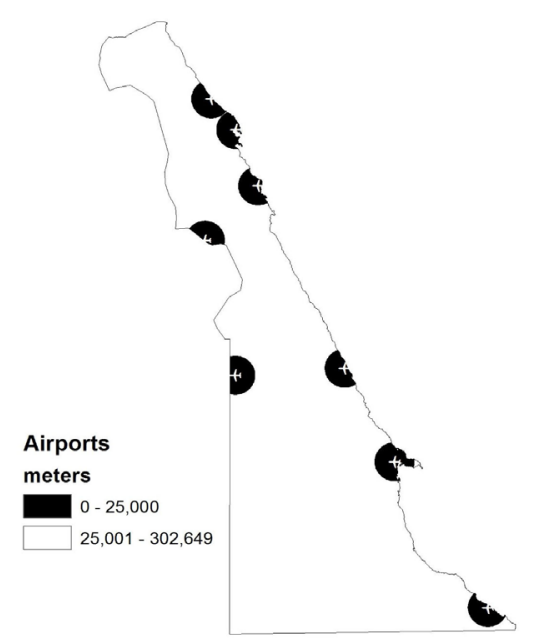

(c)

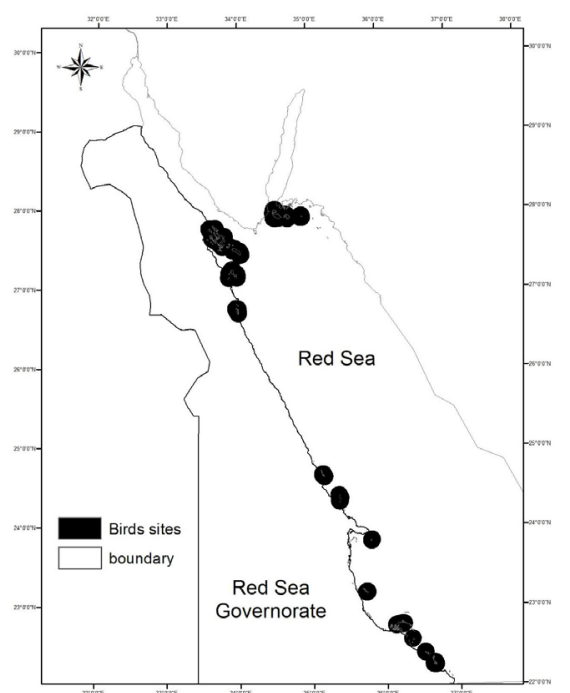

(f)

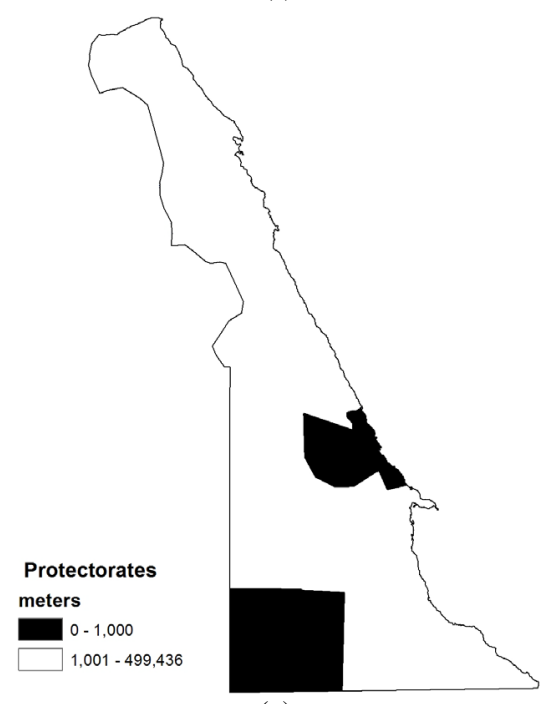

(g)

Figure 6. Ecological and cultural (constraints): (a) natural Protectorates; (b) shoreline; (c) airports; (d) cities and historical sites; (e) roads; (f) birds protection sites; (g) combined constraints map. 


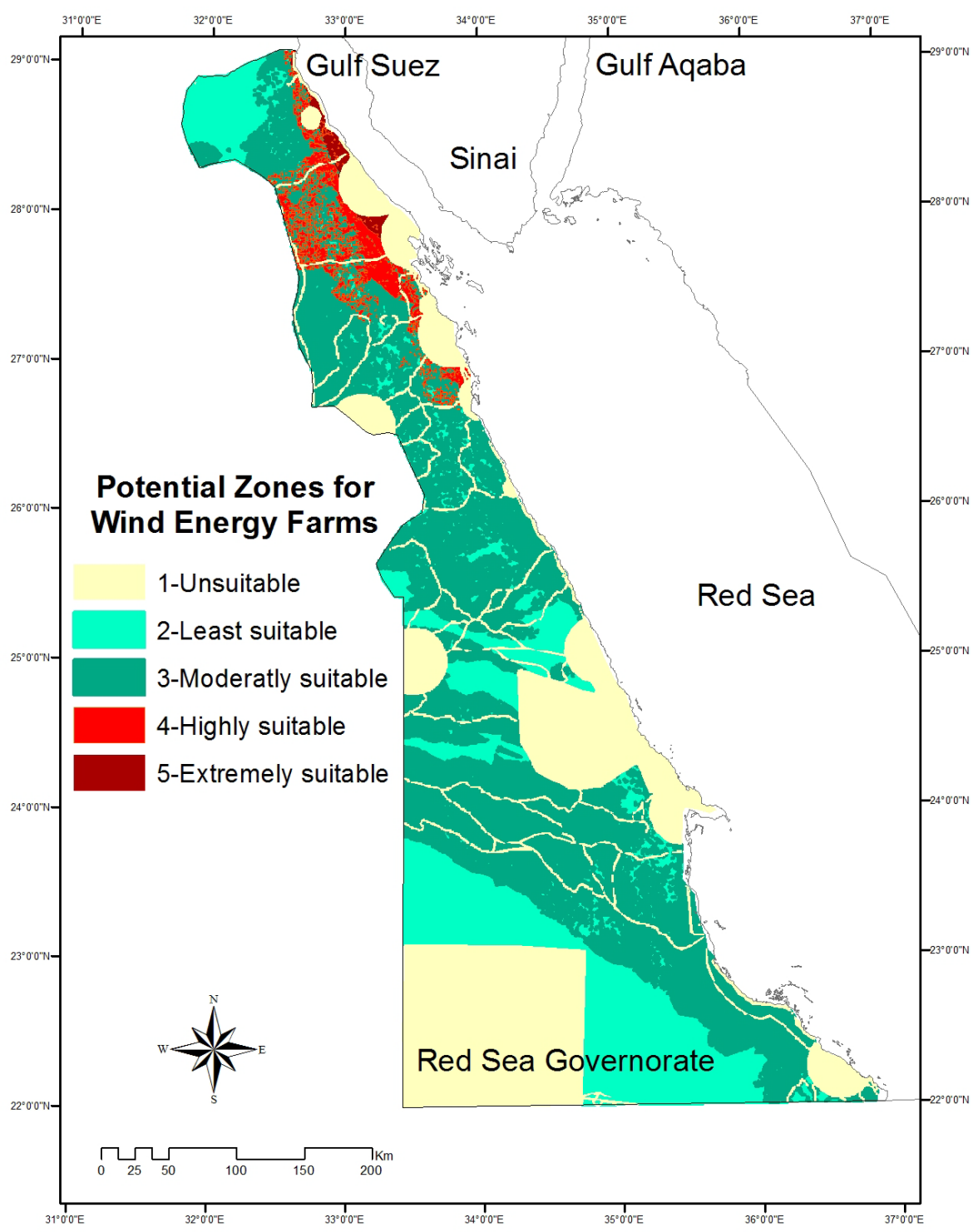

Figure 7. Suitability index for most appropriate zoning of wind farms in Red Sea Governorate.

Table 5. Standardization of the wind farm site evaluation criteria.

\begin{tabular}{cccccc}
\hline \multicolumn{5}{c}{ Standardization of the evaluation criteria standardization of evaluation factors } \\
\hline Suitability scale & $\begin{array}{c}\text { Wind power } \\
\text { density }\left(\text { watt/m }{ }^{2}\right)\end{array}$ & Slope degrees & Proximity to power lines (m) & Proximity to cities (m) & Proximity to roads (m) \\
\hline 0 & & $>=9$ & $0-249$ & $0-2000$ & $0-500$ \\
1 & $14-86$ & & $214,445-265,452$ & $286,108-321,870$ & $68,713-77,301$ \\
2 & $87-158$ & & $176,969-214,444$ & $250,344-286,107$ & $60,124-68,712$ \\
3 & $159-229$ & & $147,822-176,968$ & $214,581-250,343$ & $51,353-60,123$ \\
4 & $230-301$ & $>5$ & $123,879-147,821$ & $178,818-214,580$ & $42,946-51,352$ \\
5 & $302-373$ & & $100,977-123,878$ & $143,054-178,817$ & $34,356-42,945$ \\
6 & $374-445$ & & $77,034-100,976$ & $107,291-143,053$ & $25,768-34,356$ \\
7 & $446-516$ & & $52,050-77,033$ & $71,528-107,290$ & $17,179-25,767$ \\
8 & $517-588$ & & $24,985-52,049$ & $35,764-71,527$ & $8590-17,178$ \\
9 & $589-660$ & $<=5$ & $250-24,984$ & $2000-35,763$ & $500-8589$ \\
\hline
\end{tabular}


Table 6. Excluded zones (Constraints) threshold.

\begin{tabular}{cc}
\hline Criteria (excluded zones) & Buffer zone (m) around excluded zones \\
\hline Protectorates & $1000 \mathrm{~m}$ around protectorates \\
Shoreline & $4000 \mathrm{~m}$ around shoreline \\
Birds sites & $1000 \mathrm{~m}$ around birds sites \\
Power lines & $250 \mathrm{~m}$ around power lines \\
Cities & $2000 \mathrm{~m}$ around cities \\
Historic sites & $1000 \mathrm{~m}$ around historic sites \\
Roads & $500 \mathrm{~m}$ around roads \\
Airport & $25,000 \mathrm{~m}$ around main airports \\
Slopes & More than 9 degrees \\
\hline
\end{tabular}

Table 7. Suitable classes and land areas for wind power energy crop.

\begin{tabular}{ccccc}
\hline Class & Rang and percentage of suitability values & Class description & Area (sq. km) & Percentage of total area \\
\hline 1 & $0-0.30$ & Unsuitable & 35298.8 & 0.294 \\
2 & $0.31-0.49$ & Least suitable & 45690.7 & 0.380 \\
3 & $0.50-0.65$ & Suitable & 35300.7 & 0.294 \\
4 & $0.66-0.83$ & Highly suitable & 3781.2 & 0.031 \\
5 & $0.84-1.00$ & Extremely suitable (ideal) & 706.5 & 0.005 \\
\hline
\end{tabular}

the form of thematic maps that are comprehensive and useful for planning purposes. The method succeeds in mapping potential zones rich in wind power energy and avoiding sensitive ecological sites, while considering some economic factors such as slopes, accessibility and power network. By excluding the land constraints, the developed model identified the ideal zones with all suitability conditions for siting wind energy farms in the northern Red Sea Coast. These ideal zones amount to $706 \mathrm{~km} \cdot \mathrm{sq}$. with suitability values of $83 \%-100 \%$. Also, highly suitable zones amounting to $3781 \mathrm{~km} \cdot \mathrm{sq}$. with suitability values of $66 \%-83 \%$ have been determined. Thus multi-objectives could be reached. The results of the current study highlights the need of adopting a holistic integrated approach that integrates land resources, potentials and constraints in the land-use decision strategies for achieving sustainable planning at a regional scale. Applying such techniques unveils the relationship between potential resources and vulnerable features that can be spatially competing. Thus providing indicator maps; as a guide for zoning and land-use strategies. The methodology is applicable and can be conducted for creating zoning maps of wind power energy in other regions.

Based on the output of this study, potential zones in each individual location should be field investigated and an environmental impact assessment to be further assessed. It is highly recommended that the land-use decision makers adopt the Spatial Multicriteria Evaluation analysis. Such method is believed to overcome the shortcomings of the current planning practice especially in developing countries, due to need of a multidisciplinary approach and evaluation tools in the land-use planning decisions.

\section{References}

[1] Fernandez, L.M., Saenz, J.R. and Jurado, F. (2006) Dynamic Models of Wind Farms with Fixed Speed Wind Turbines. Renewable Energy, 31, 1203-1230. http://dx.doi.org/10.1016/j.renene.2005.06.011

[2] Tester, J.W., Drake, E.M., Driscoll, M.J., Golay, M.W. and Peters, W.A. (2005) Sustainable Energy; Choosing among Options. The MIT Press, Cambridge.

[3] Ramirez-Rosado, I.J.R., Garrido, E.G., Jimerenz, L.A.F., Zorzano-Santamar, P.J., Monteiro, C. and Miranda, V. (2008) Promotion of New Wind Farms Based on a Decision Support System. Renewable Energy, 33, 558-566. http://dx.doi.org/10.1016/j.renene.2007.03.028

[4] Baban, S.M.J. and Parry, T. (2001) Developing and Applying a GIS-Assisted Approach to Locating Wind Farms in the UK. Renewable Energy, 24, 59-71. http://dx.doi.org/10.1016/S0960-1481(00)00169-5

[5] Nguyen, K.Q. (2007) Wind Energy in Vietnam: Resource Assessment, Development Status and Future Implications. Energy Policy, 35, 1405-1413. http://dx.doi.org/10.1016/j.enpol.2006.04.011

[6] Yue, C.D. and Wang, S.S. (2006) GIS-Based Evaluation of Multifarious Local Renewable Energy Sources: A Case 
Study of the Chigu Area of Southwestern Taiwan. Energy Policy, 34, 730-742. http://dx.doi.org/10.1016/j.enpol.2004.07.003

[7] Bennui, A., Rattanamanee, P., Puetpaiboon, U., Phukpattaranont, P. and Chetpattananondh, K. (2007) Site Selection for Large Wind Turbines Using GIS. PSU-UNS International Conference on Engineering and Environment-ICEE2007, Phuket, May 10-11, 2007, 90112.

[8] Patel, B. and Rosier, A. (2013) Basic Criteria for Wind Project Site Selection and Optimization. ECOWAS Regional Workshop on Wind Energy. Pria, Cape Verde.

http://www.ecreee.org/sites/default/files/event-att/wind project site optimization.pdf

[9] Elliasson, B. (1998) Energy and Global Changes. ABB Corporate Research.

[10] Walker, J.F. and Jenkens, N. (1997) Wind Energy Technology. John Wiley \& Sons, Chichester.

[11] Afgan, N.H. and Carvalho, M.G. (2002) Multi-Criteria Assessment of New and Renewable Energy Power Plants. Energy, 27, 739-755. http://dx.doi.org/10.1016/S0360-5442(02)00019-1

[12] Malczewski, J. (1999) GIS and Multicriteria Decision Analysis. John Wiley and Sons, Inc., New York.

[13] Wood, L.J. and Dragicevic, S. (2007) GIS-Based Multicriteria Evaluation and Fuzzy Sets to Identify Priority Sites for Marine Protection. Biodiversity and Conservation, 16, 2539-2558. http://dx.doi.org/10.1007/s10531-006-9035-8

[14] Mann, D., Lant, C. and Schoof, J. (2012) Using Map Algebra to Explain and Project Spatial Patterns of Wind Energy Development in Iowa. Applied Geography, 34, 219-229. http://dx.doi.org/10.1016/j.apgeog.2011.11.008

[15] Bartnicki, N. and Willamson, M. (2012) An Integrated GIS Approach to Wind Power Site Selection in Huron County, Ontario. Department of Geography, University of Guelph, Guelph.

[16] Rodman, L.C. and Meentemeyer, R.K. (2006) A Geographic Analysis of Wind Turbine Placement in Northern California. Energy Policy, 34, 2137-2149. http://dx.doi.org/10.1016/j.enpol.2005.03.004

[17] Shobrak, M., Al-Suhaibany, A. and Al-Sagheir, O. (2003) Regional Status of Breeding Seabirds in the Red Sea and the Gulf of Aden. The Regional Organization for the Conservation of the Environment of the Red Sea and Gulf of Aden (PERSGA). http://www.persga.org/Files/Common/Sea_Birds/Reginal_Status_of_Seabirds.pdf

[18] El-Din, M.B., El-Din, S.B. and Shobrak, M. (2003) Status of Breeding Seabirds in the Egyptian Red Sea. Report for PERSGA, Jeddah, $30 \mathrm{p}$.

[19] Ministry of State of Environmental Affairs, Egyptian Environmental Affairs Agency (EEAA) (2014) Important Bird Areas (IBAs) of Egypt. http://www.eeaa.gov.eg/english/main/protect_bird.asp

[20] El-Din, S.B. (1999) Directory of Important Bird Areas in Egypt. Birdlife International, The Palm Press, Cairo.

[21] Collar, N.J., Crosby, M.J. and Stattersfield, A.J. (1994) Birds to Watch 2. Birdlife International, Cambridge.

[22] Shata, A.S. and Hanitsch, R. (2006) The Potential of Electricity Generation on the East Coast of Red Sea in Egypt. Renewable Energy, 31, 1597-1615. http://dx.doi.org/10.1016/j.renene.2005.09.026

[23] Mortensen, N.G., Hansen, J.C., Badger, J., Jørgensen, B.H., Hasager, C.B., Youssef, L.G., Said, U.S., et al. (2005) Wind Atlas for Egypt, Measurements and Modeling. Wind Atlas for Egypt: Measurements, Micro and Mesoscale Modeling. http://www.windatlas.dk/egypt/download/wind\%20atlas\%20for\%20egypt\%20paper\%20(menarec3).pdf

[24] (2006) ESRI Arc Map Help. Version 9.2, User Manual, ESRI, Redlands.

[25] The Egyptian General Survey Authority (1989) Topographic Maps at Scale 1:50,000.

[26] Egyptian Meteorological Authority (1996) Climatic Atlas of Egypt.

[27] Saaty, T.L. (1980) The Analytic Hierarchy Process. McGraw-Hill, New York, 20-25.

[28] Lee, A.H.I., Chen, W.C. and Chang, C.J. (2008) A fuzzy AHP and BSC Approach for Evaluating Performance of IT Department in the Manufacturing Industry in Taiwan. Expert Systems with Applications, 34, 96-107. http://dx.doi.org/10.1016/j.eswa.2006.08.022

[29] Vahidnia, M.H., Alesheikhb, A., Alimohammadic, A. and Bassiri, A. (2008) Fuzzy Analytical Hierarchy Process in GIS Application. The International Archives of the Photogrammetry, Remote Sensing and Spatial Information Sciences, 37, 593-596.

[30] Eastman, J.R., Jin, W., Kyem, P.A.K. and Toledano, J. (1995) Raster Procedures for Muli-Criteria/Multiobjective Decisions. Photogrammetric Engineering \& Remote Sensing, 61, 539-547.

[31] Vanek, F.M. and Albright, L.D. (2008) Energy Systems Engineering-Evaluation and Implementation. McGraw-Hill, New York.

[32] Hughes, T. (2000) Calculation of Wind Energy and Power. Lesson Number 1 in an Oklahoma Wind Power Tutorial Series. http://www.seic.okstate.edu/owpi_old/about/library/lesson1_windenergycalc.pdf

[33] Nextra Energy Canada (2011) Conestogo Wind Farm, Revised Construction Plan Report. Nextra Enegy Canada, 
Conestogo Project.

http://www.nexteraenergycanada.com/pdf/conestogo/Revised_Conestogo_Construction_Report_FINALv1.pdf

[34] Moiloa, B.H.E. (2009) Geographical Information Systems for Strategic Wind Energy Site Selection. M.Sc. Thesis, Faculty of Earth and Life Sciences, Vrije University, Amsterdam.

[35] DEADP (2006) Strategic Initiative to Introduce Commercial Land Based Wind Energy Development to the Western Cape: Towards a Regional Methodology for Wind Energy Site Selection, Report Series 1-7. Department of Environmental Affairs and Development Planning, Cape Town.

[36] CNdV Africa Planning and Design (2006) Strategic Initiative to Introduce Commercial Land Based Wind. Energy Development to the Western Cape. Towards a Regional Methodology to Wind Energy Site Selection. Report 2. Methodology 1. Prepared for Provincial Government Wind Energy Landscapes: Specialist Study: Report 2. Methodology 1, 9-11. http://ebookbrowsee.net/3-report-2-method-1-criteria-based-assessment-pdf-d251378713

[37] Luo, C., Banakar, H., Shen, B. and Ooi, B.T. (2007) Strategies to Smooth Wind Power Fluctuations of Wind Turbine Generator. IEEE Transactions on Energy Conversion, 22, 341-349. http://dx.doi.org/10.1109/TEC.2007.895401

[38] Effat, H.A. and Hegazy, M.N. (2013) A Multidisciplinary Approach to Mapping Potential Urban Development Zones in Sinai Peninsula, Egypt, using Remote Sensing and GIS. Journal of Geographic Information System, 5, 567-583 http://dx.doi.org/10.4236/jgis.2013.56054

[39] Effat, H.A. (2014) Resource-Based Zoning Map for Sustainable Industrial Development in North Sinai using Remote Sensing and Multicriteria Evaluation. International Journal of Sustainable Development and Planning, 9, 119-134. 
Scientific Research Publishing (SCIRP) is one of the largest Open Access journal publishers. It is currently publishing more than 200 open access, online, peer-reviewed journals covering a wide range of academic disciplines. SCIRP serves the worldwide academic communities and contributes to the progress and application of science with its publication.

Other selected journals from SCIRP are listed as below. Submit your manuscript to us via either submit@scirp.org or Online Submission Portal.
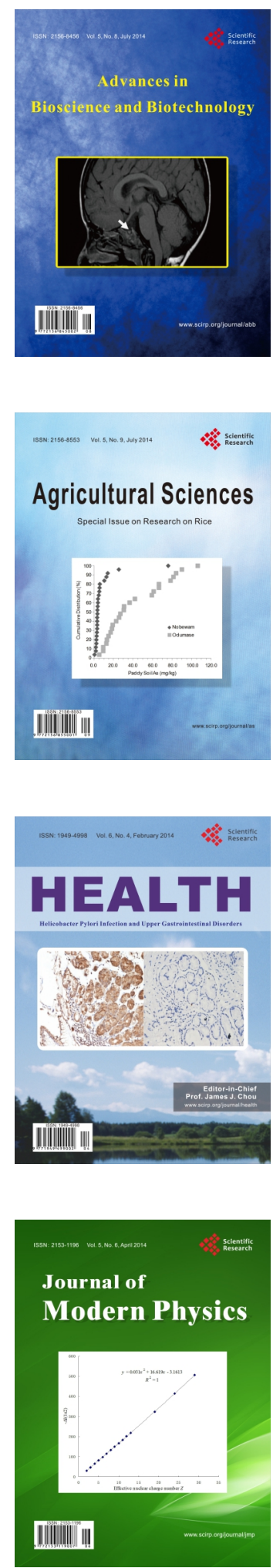
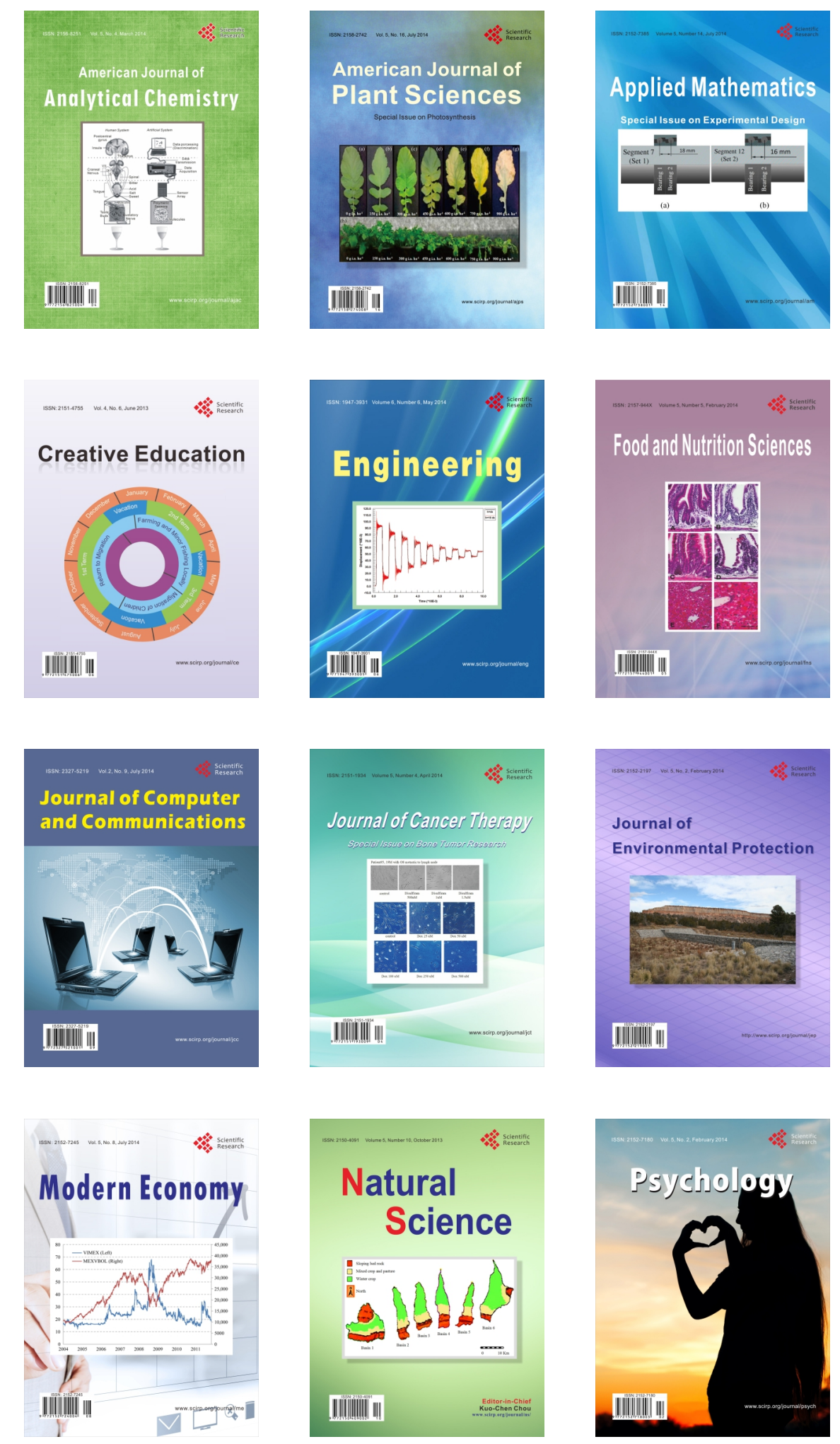